\title{
СТАТЕВІ ВІДМІННОСТІ ВІЛЬНОРАДИКАЛЬНИХ ПРОЦЕСІВ У МІОКАРДІ ПРИ УШКОДЖЕННІ АДРЕНАЛІНОМ НА ТЛІ СВІТЛОВОЇ ДЕПРИВАЦІЇ
}

Вступ. Ішемічна хвороба серця - основна причина смерті, й частіше вона виникає в чоловіків. Серед фракторів ризику головним є стрес. При цьому порушується баланс системи прооксиданти/антиоксиданти. Серед антиоксидантів важливе місце займає мелатонін, який зменшує ушкодження міокарда за умов гіперкатехоламінемії. На сьогодні недостатньо вивчено питання щодо гендерної відмінності кардіопротекторних ефектів мелатоніну при порушеній активності пінеальної залози.

мета дослідження - встановити статеві відмінності вільнорадикальних процесів у міокарді при розвитку некротичного процесу на тлі світлової депривації.

Методи дослідження. У міокарді шлуночків самців і самиць щурів визначали активність пероксидного окиснення ліпідів (ПОЛ) та антиоксидантної системи при ушкодженні адреналіном. Некроз міокарда моделювали шляхом введення адреналіну (0,5 мг/ка) у м'яз на тлі світлової депривації (10 днів повної темряви, освітлення 0,5-1 LX). Група контролю складалася з тварин, які перебували в умовах збереженого режиму зміни циклів день/ніч (12 год освітлення 500 LX/12 год темряви 0,5-1 LX).

Результати й обговорення. Розвиток некротичного процесу в міокарді щурів на тлі десятидобової світлової депривації характеризувався меншою активацією ПОЛ порівняно з показниками тварин групи контролю. Це підтверджувалося меншим вмістом продуктів ПОЛ у міокарді шлуночків. Активність антиоксидантної системи за таких умов була більшою, ніж у тварин групи контролю, особливо в самиць. Ця закономірність свідчила про позитивний вплив попередньої десятидобової світлової депривації на розвиток некротичного процесу в міокарді, що можна пояснити посиленим синтезом мелатоніну, який $є$ антиоксидантом, а також була характерна для щурів обох статей, але кардіопротекторний ефект світлової депривації більш істотним був у самиць.

Висновок. Світлова депривація сприяє захисту серця від ушкодження адреналіном, про що свідчать менша активність пероксидного окиснення ліпідів і більша активність ензимів антиоксидантної системи, особливо в самиць.

КЛЮЧОВІ СЛОВА: світлова депривація; некроз міокарда; ліпопероксидація; статеві відмінності.

ВСТУП. Проблема високої смертності людей працездатного віку залишається пріоритетною при встановленні причин демографрічної кризи не лише в Україні, але й країнах з подібним економічним рівнем. Серед захворювань, які демонструють найвищі показники, домінують серцево-судинні, зокрема ішемічна хвороба серця, найнебезпечнішим проявом якої $€$ інфраркт міокарда. У генезі їх розвитку важливе місце відводять стресу як фрактору ризику, ініціація якого передбачає патогенний вплив адреналіну [1-3]. Адреналін має як прямий негативний вплив на міокард, так і опосередкований суттєвими порушеннями метаболізму, що призводить до незворотного ушкодження кардіоміоцитів [4, 5]. Визна(с Г. О. Безкоровайна, І. М. Кліщ, М. Р. Хара, 2019. чальним за таких умов є стан антиоксидантної системи, активність якої залежить від швидкості та інтенсивності утворення вільнорадикальних сполук і швидкості використання проміжних продуктів пероксидного окиснення ліпідів (ПОЛ) у синтезі біологічно активних речовин у ділянці ушкодження $[1,6]$. У групі антиоксидантів належне місце займає мелатонін, синтез якого залежить від активності пінеальної залози $[7,8]$. Саме ця залоза визначає еорективність циркадіанних ритмів і тонко реагує на порушення світлового режиму. Важливу роль світлового десинхронозу в перебізі кардіальної патології доведено науковими дослідженнями [8]. У цьому контексті привертає також увагу новий підхід до корекції стану кардіологічних пацієнтів з урахуванням 
циркадіанних ритмів для збільшення еорективності терапії [9]. Новим у сучасній медицині $€$ й гендерний підхід до вирішення зазначених проблем. На доклінічному рівні доведено статеву відмінність у здатності мелатоніну захищати міокард від ушкодження, зокрема адреналіном. Показано, що серце самиць щурів за таких умов краще захищене, ефекти мелатоніну також $€$ суттєвішими, і визначальну роль у цьому відіграють статеві гормони, зокрема естрогени [5, 10]. Невирішеним залишається питання щодо ролі ендогенного мелатоніну при збереженому та порушеному режимі його синтезу в патогенезі некрозу міокарда.

Мета дослідження - встановити статеві відмінності вільнорадикальних процесів у міокарді при розвитку некротичного процесу на тлі світлової депривації.

МЕТОДИ ДОСЛІДЖЕННЯ. Досліди виконано на білих лабораторних статевозрілих самцях і самицях щурів масою 250-270 г. Тварин утримували 10 діб в умовах повної темряви (0,5$1 \mathrm{LX})$. На 11-й день моделювали некротичне ушкодження міокарда (НУМ) шляхом введення адреналіну (0,5 мг/кг) в м'яз. У міокарді шлуночків через 1 та 24 год після введення адреналіну визначали вміст дієнових кон'югатів (ДК), малонового діальдегіду (МДА), активність супероксиддисмутази (СОД), каталази (КАТ), вміст сульфгідрильних груп (SH-груп), активність глутатіонредуктази (ГР) та глутатіонпероксидази (ГП) [11-16]. Отримані показники аналізували, порівнюючи з аналогічними у тварин, які перебували в умовах режиму освітлення зі зміною циклів день/ніч (12 год освітлення 500 LX/12 год темряви 0,5-1 LX). Забір серця для дослідження (евтаназія) здійснювали під тіопенталовим наркозом. Для статистичної обробки даних використову- вали комп'ютерну програму Microsoft Excel XP (США). Усі експерименти проводили з дотриманням правил біоетики.

РЕЗУЛЬТАТИ Й ОБГОВОРЕННЯ. РОЗВИТОК некротичного процесу в міокарді шлуночків за умов світлової депривації відбувався на тлі менш активних вільнорадикальних процесів. Це підтверджувалося нижчим вмістом ДК та МДА порівняно $з$ показниками тварин групи контролю (ГК) (табл. 1). Характер динаміки показників зі збільшенням часу спостереження був аналогічним такому в ГК. Вміст ДК у міокарді шлуночків $\sigma^{x}$ на 1 год НУМ підвищився в 3,9 раза, через 24 год - у 5,8 раза, а в + - у 3,4 та 5,3 раза відповідно. Порівняно з ГК абсолютні значення були достовірно меншими в обидва терміни розвитку НУМ: у о на 1 та 24 год - 11 та $37 \%$ відповідно, а в 우 - 26 і 36 \%. Динаміка МДА у тварин групи "темрява" (ГТ) була аналогічною такій у ГК. Приріст показника в от становив 2,9 та 4,8 раза, в ㅇ - 3,0 і 3,8 раза відповідно на 1 та 24 год НУМ. При даній моделі світлового десинхронозу абсолютні значення вмісту МДА були нижчими, ніж у ГК, зокрема в $0^{x}-$ на 26 та $19 \%$, а в + - на 24 і 35 \% відповідно на 1 та 24 год НУМ. Менші, порівняно з ГК, значення цих показників демонстрували нижчу активність мембраноруйнівних процесів. Крім того, вміст МДА в міокарді ㅇ на 24 год виявився на $44 \%$ меншим, ніж у $\sigma^{x}$. Це відображало кращий захист серця, ймовірно, за рахунок не лише антиоксидантних властивостей естрогенів, але й гормону пінеальної залози, синтез якого за умов тривалої темряви зростає. Дане твердження підтвердили наукові дані, які демонструють кращий кардіопротекторний ефрект мелатоніну в 우 [10].

Динаміка активності СОД і КАТ при розвитку НУМ на тлі світлової депривації була подібною

Таблиця 1 - Вміст продуктів пероксидного окиснення ліпідів у міокарді щурів при ушкодженні адреналіном на тлі світлової депривації (M $\pm \sigma)$

\begin{tabular}{|c|c|c|c|c|}
\hline Показник & Стать & $\begin{array}{c}\text { Контроль } \\
(\mathrm{n}=6)\end{array}$ & $\begin{array}{c}\text { Адреналін } 1 \text { год } \\
(n=6)\end{array}$ & $\begin{array}{c}\text { Адреналін } 24 \text { год } \\
(n=6)\end{array}$ \\
\hline \multicolumn{5}{|c|}{ Група контролю } \\
\hline \multirow{2}{*}{\begin{tabular}{|l} 
ДК, \\
ум. од./кг
\end{tabular}} & $0^{x}$ & $0,17 \pm 0,01$ & $0,39 \pm 0,02^{\star}$ & $0,71 \pm 0,04^{\star \#}$ \\
\hline & 우 & $0,16 \pm 0,01$ & $0,34 \pm 0,02^{\star}$ & $0,57 \pm 0,03^{\star \#}$ \\
\hline \multirow{2}{*}{\begin{tabular}{|l|} 
МДА, \\
мкмоль/кг
\end{tabular}} & $\sigma^{x}$ & $1,24 \pm 0,03$ & $3,79 \pm 0,12^{\star}$ & $5,93 \pm 0,18^{\star \#}$ \\
\hline & 우 & $1,33 \pm 0,05$ & $3,44 \pm 0,06^{*}$ & $4,67 \pm 0,09^{\star \#}$ \\
\hline \multicolumn{5}{|c|}{ Група "темрява" } \\
\hline \multirow{2}{*}{\begin{tabular}{|l|} 
ДК, \\
ум. од./кг
\end{tabular}} & $0^{x}$ & $0,09 \pm 0,01^{\wedge}$ & $0,35 \pm 0,02^{\star^{\wedge}}$ & $0,52 \pm 0,02^{\star^{\wedge}}$ \\
\hline & 우 & $0,08 \pm 0,01^{\wedge}$ & $0,27 \pm 0,02^{\star \wedge}$ & $0,42 \pm 0,01^{\star^{\wedge}}$ \\
\hline \multirow{2}{*}{\begin{tabular}{|l|} 
МДА, \\
мкмоль/кг
\end{tabular}} & $\sigma^{T}$ & $1,05 \pm 0,07^{\wedge}$ & $3,00 \pm 0,11^{\star^{\wedge}}$ & $5,00 \pm 0,08^{\star \wedge \#}$ \\
\hline & 우 & $0,92 \pm 0,04^{\wedge}$ & $2,78 \pm 0,20^{\star \wedge}$ & $3,47 \pm 0,11^{\star^{\wedge}}$ \\
\hline
\end{tabular}

Примітки. Тут і в таблиці 2:

1. * - достовірна $(p \leq 0,05)$ відмінність відносно контролю в межах групи дослідження.

2. ^ - відносно показника групи контролю в аналогічний період спостереження.

3. \# - відносно тварин протилежної статі. 
до такої в ГК. На 1 год розвитку НУМ обидва показники підвищувалися, зокрема, в от - на 76 та $76 \%$ відповідно, а в ㅇ - на 55 і $101 \%$ (табл. 2). На 24 год спостереження показники збільшувались, відповідно, на $41 \%$ та 2,7 раза в о і $45 \%$ та 2,2 раза в ㅇ. . При цьому в представників обох статей активність СОД була достовірно вищою, ніж у ГК, а КАТ - нижчою. У першому випадку така відмінність демонструвала менший ступінь депресії СОД у динаміці накопичення вільнорадикальних сполук, що могло бути наслідком активнішої участі ендогенного мелатоніну в системі антиоксидантного захисту [17]. У випадку з каталазою нижча, порівняно з ГК, активність ензиму відображала менш інтенсивне накопичення пероксиду водню, що також свідчило про меншу інтенсивність утворення вільнорадикальних сполук. Статистично значимої різниці між різностатевими тваринами за цими показниками не було.

Динаміка активності ензимів глутатіонової групи за умов НУМ у ГТ була аналогічною такій у ГК. Щоправда, активність ГПу міокарді ㅇ була достовірно меншою, що корелювало $з$ нижчою активністю каталази, а ГР - більшою за показники ГК, що на 24 год розвитку НУМ становило, відповідно, 12 та 28 \%. Попри зменшення в динаміці розвитку НУМ вмісту сульфгідрильних груп, їх значення все ж таки було достовірно вищим, ніж у ГК. У $\sigma^{x}$ на 1 та 24 год розвитку НУМ даний показник переважав порівнюване значення, відповідно, на 60 та $81 \%$, а в - на 50 і $59 \%$. За цим показником ㅇ переважали от на 41 \% (у ГК - на 61 \%), що свідчило про менш інтенсивне використання системи глутатіону для стримування вільнорадикальних процесів, імовірно, за рахунок більшої есрективності першої лінії захисту (СОД, КАТ).

Загальний аналіз динаміки досліджуваних показників дозволяє стверджувати, що десятидобова світлова депривація, яка сприяє підвищенню активності пінеальної залози та активнішому синтезу мелатоніну, є фрактором кардіопротекції, що підтверджується меншим ступенем активації ПОЛ за умов гострої гіперкатехоламінемії. При цьому активність антиоксидантного захисту є більш збалансованою. Адже при розвитку некротичного процесу на піку некрозоутворення та ПОЛ (24 год після введення адреналіну) активність СОД та вміст сульсргідрильних груп є вищими, ніж за збереженого світлового режиму. Це відображає умови менш активного накопичення активних фрорм кисню та пероксидних сполук, зокрема пероксиду водню, що підтверджується нижчою активністю каталази. Варто зазначити, що як за збереженого світлового режиму, так і при світловій депривації інтенсивність вільнорадикальних процесів у міокарді шлуночків самиць виявилася достовірно меншою, ніж у самців. Таку відмінність можна пояснити антиоксидантними властивостями як естрогенів, так і мелатоніну [18, 19].

Таблиця 2 - Показники антиоксидантної системи міокарда щурів

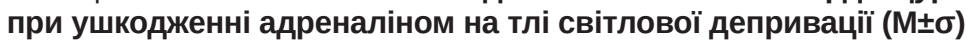

\begin{tabular}{|c|c|c|c|c|}
\hline Показник & Стать & $\begin{array}{l}\text { Контроль } \\
(\mathrm{n}=6)\end{array}$ & $\begin{array}{c}\text { Адреналін } 1 \text { год } \\
(\mathrm{n}=6)\end{array}$ & $\begin{array}{c}\text { Адреналін } 24 \text { год } \\
(\mathrm{n}=6)\end{array}$ \\
\hline \multicolumn{5}{|c|}{ Контрольна група } \\
\hline \multirow{2}{*}{$\begin{array}{l}\text { СОД, } \\
\text { ум. од./кг }\end{array}$} & $\sigma^{\top}$ & $0,42 \pm 0,01$ & $0,55 \pm 0,01^{*}$ & $0,32 \pm 0,02^{*}$ \\
\hline & 우 & $0,39 \pm 0,01$ & $0,49 \pm 0,03^{*}$ & $0,38 \pm 0,01$ \\
\hline \multirow{2}{*}{$\begin{array}{l}\text { КАТ, } \\
\text { мкат/кг }\end{array}$} & $\sigma^{x}$ & $0,97 \pm 0,03$ & $1,56 \pm 0,09^{*}$ & $3,43 \pm 0,29$ *\# \\
\hline & 우 & $0,86 \pm 0,04$ & $1,45 \pm 0,11^{*}$ & $2,33 \pm 0,31^{\star \#}$ \\
\hline \multirow{2}{*}{$\begin{array}{l}\text { SH-групи, } \\
\text { ммоль/кг }\end{array}$} & $\sigma^{x}$ & $2,48 \pm 0,08$ & $1,61 \pm 0,09^{*}$ & $0,90 \pm 0,04^{\text {*\# }}$ \\
\hline & 우 & $2,42 \pm 0,07$ & $1,90 \pm 0,08^{\star}$ & $1,45 \pm 0,06^{\star \#}$ \\
\hline \multirow{2}{*}{$\begin{array}{l}\text { ГР, } \\
\text { ммоль/(Хв·кг) }\end{array}$} & $0^{x}$ & $0,27 \pm 0,01$ & $0,18 \pm 0,01^{*}$ & $0,15 \pm 0,01^{*}$ \\
\hline & 우 & $0,31 \pm 0,01$ & $0,21 \pm 0,01^{*}$ & $0,18 \pm 0,01^{*}$ \\
\hline \multirow{2}{*}{$\begin{array}{l}\text { ГП, } \\
\text { ммоль/(хв·кг) }\end{array}$} & $\sigma^{x}$ & $0,42 \pm 0,01$ & $0,56 \pm 0,02^{*}$ & $0,35 \pm 0,01^{*}$ \\
\hline & 우 & $0,39 \pm 0,01$ & $0,49 \pm 0,02^{*}$ & $0,38 \pm 0,01$ \\
\hline \multicolumn{5}{|c|}{ Група "темрява" } \\
\hline \multirow{2}{*}{$\begin{array}{l}\text { СОД, } \\
\text { ум. од./кг }\end{array}$} & $\sigma^{x}$ & $0,37 \pm 0,01$ & $0,65 \pm 0,01^{*^{\wedge}}$ & $0,52 \pm 0,02^{\star^{\wedge}}$ \\
\hline & 우 & $0,38 \pm 0,02$ & $0,59 \pm 0,02^{\star^{\wedge}}$ & $0,55 \pm 0,02^{\star^{\wedge}}$ \\
\hline \multirow{2}{*}{$\begin{array}{l}\text { КАТ, } \\
\text { мкат/кг }\end{array}$} & $\sigma^{\top}$ & $0,92 \pm 0,19$ & $1,62 \pm 0,14^{\star}$ & $2,48 \pm 0,16^{\star^{\wedge}}$ \\
\hline & 우 & $0,78 \pm 0,08$ & $1,57 \pm 0,17^{*}$ & $1,73 \pm 0,26^{\star^{\wedge}}$ \\
\hline \multirow{2}{*}{$\begin{array}{l}\text { SH-групи, } \\
\text { ммоль/кг }\end{array}$} & $\sigma^{x}$ & $3,68 \pm 0,16^{\wedge}$ & $2,57 \pm 0,10^{\star \wedge}$ & $1,63 \pm 0,10^{\star \wedge \#}$ \\
\hline & 우 & $3,70 \pm 0,21^{\wedge}$ & $2,85 \pm 0,06^{\star^{\wedge}}$ & $2,30 \pm 0,08^{\star \wedge \#}$ \\
\hline \multirow{2}{*}{$\begin{array}{l}\text { ГР, } \\
\text { ммоль/(хв·кг) }\end{array}$} & $\sigma^{T}$ & $0,30 \pm 0,01$ & $0,21 \pm 0,01^{\star \#}$ & $0,19 \pm 0,02^{*}$ \\
\hline & 우 & $0,34 \pm 0,03$ & $0,26 \pm 0,01^{\star^{\wedge} \#}$ & $0,23 \pm 0,01^{\star^{\wedge}}$ \\
\hline \multirow{2}{*}{$\begin{array}{l}\text { ГП, } \\
\text { ммоль/(хв·кг) }\end{array}$} & $\sigma^{x}$ & $0,39 \pm 0,01$ & $0,51 \pm 0,01^{*}$ & $0,32 \pm 0,01^{*}$ \\
\hline & 우 & $0,38 \pm 0,02$ & $0,44 \pm 0,01^{*}$ & $0,34 \pm 0,01^{\wedge}$ \\
\hline
\end{tabular}


ВИСНОВКИ. Розвиток некротичного процесу в міокарді на тлі десятидобової світлової депривації характеризується меншою інтенсивністю пероксидного окиснення ліпідів та більш оптимальним балансом системи прооксиданти/антиоксиданти, що забезпечується вищою актив- ністю супероксиддисмутази та глутатіонредуктази, і відображає кардіопротекторний ефект змодельованої гіперфункції пінеальної залози. У гендерному аспекті активність мембраноруйнівних процесів за даної моделі ушкодження міокарда $€$ нижчою в самиць щурів.

\section{СПИСОК ЛІТЕРАТУРИ}

1. Барабой В. А. Фізіологія, біохімія і психологія стресу / В. А. Барабой, О. Г. Рєзніков. - К., 2013. $314 \mathrm{c}$.

2. Boland T. A. Stress-induced cardiomyopathy / T. A. Boland, V. H. Lee, T. P. Bleck. // Crit. Care Med. 2015. - 43 (3). - P. 686-693.

3. Prasad A. Apical ballooning syndrome (Tako-Tsubo or stress cardiomyopathy): a mimic of acute myocardial infarction / A. Prasad, A. Lerman, C. S. Rihal // Am. Heart J. - 2008. - 155 (3). - P. 408-417.

4. Fatal catecholamine-induced cardiotoxicity associated with pheochromocytoma: Report of a postpartum case and review of the literature /A. R. Wang, S. A. Dean, S. K. Grebe, I. C. Hood // Acad. Forensic Pathol. -2016. 6 (2). - P. 315-324.

5. Хара М. Р. Характеристика ступеня пошкодження міокарда адреналіном у щурів різної статі залежно від тривалості спостереження та рівня статевих гормонів / М. Р. Хара, О. В. Шкумбатюк, Л. І. Кучирка // Вісн. морфології. - 2014. - 20, № 2 - С. 372-375.

6. Перекисное окисление липидов: противоречия проблемы / В. К. Казимирко, Л. Н. Иваницкая, В. В. Кутовой [и др.] // Укр. ревматол. журн. - 2014. № 3 (57). - C. 13-17.

7. Jiki Z. Cardiovascular benefits of dietary melatonin: A myth or a reality? [Електронний ресурc] / Z. Jiki, S. Lecour, F. Nduhirabandi // Front Physiol. -2018. -9. P. 528. - Access mode : https://www.ncbi.nlm.nih.gov/ pmc/articles/PMC5967231/

8. Mitochondria: Central organelles for melatonin's antioxidant and anti-aging actions [Електронний реcypc] / Reiter J. Russel, Dun Xian Tan, S. Rosales-Corral [et al.] // Molecules. - 2018. - 23 (2). - P. 509. - Access mode : https://www.ncbi.nlm.nih.gov/pmc/articles/ PMC6017324/

9. Glen Pyle W. Circadian rhythms influence cardiovascular disease differently in males and females: role of sex and gender [Електронний ресурс] / W. Glen Pyle, Tami A. Martino // Current Opinion in Physiology. - 2018. 5. -P. 30-37. -Access mode : https://www.sciencedirect. com/science/article/pii/S2468867318300671

10. Хара М. Р. Статеві відмінності метаболічних змін в міокарді при розвитку некротичного процесу на тлі мелатоніну / М. Р. Хара, О. В. Шкумбатюк // Актуальные проблемы транспортной медицины. - 2014. 2 (36-II), № 2. - C. 47-52.

11. Гаврилов В. Б. Спектрофротометрическое определение содержания гидроперекисей липидов в плазме крови / В. Б. Гаврилов, М. И. Мишкорудная // Лаб. дело. - 1983. - № 3. - С. 33-35.

12. Андреева Л. И. Модисикация метода определения перекисей липидов в тесте с тиобарбитуровой кислотой / Л. И. Андреева, Л. А. Кожемякин, А. А. Кишкун // Лаб. дело. - 1988. - № 11. - С. 41-43.

13. Чевари С. Роль супероксиддисмутазы в окислительных процесах клетки и метод определения ее в биологическом материале / С. Чевари, И. Чаба, Й. Сокей // Лаб. дело. - 1985. - № 11. - С. 678-681.

14. Королюк М. А. Метод определения активности каталазы / М. А. Королюк, Л. И. Иванова, И. Г. Майорова // Лаб. дело. - 1988. - № 1. - С. 16-19.

15. Веревкина Н. В. Колориметрический метод определения SH-групп и SS-связей в белках при помощи 5,5-дитиобис (2-нитробензоновой) кислоты / Н. В. Веревкина, А. И. Точилкин, Н. А. Попова // Современные методы в биохимии. - М. : Медицина, 1977. - С. 223-231.

16. Кругликова Г. О. Глутатіонпероксидазна та глутатіонредуктазна активність печінки щурів після введення селеніту натрію/Г. О. Кругликова, Ц. М. Штутман // Укр. біохім. журн. - 1976. - № 48 (2). - С. 227 233.

17. Melatonin: an ancient molecule that makes oxygen metabolically tolerable/L. C. Manchester, A. CotoMontes, J. A. Boga [et al.] // J. Pineal Res. - 2015. 59 (4). - P. 403-419.

18. Хара М. Р. Перекисне окиснення ліпідів у міокарді при розвитку некротичного процесу на тлі мелатоніну та різної активності гонад / М. Р. Хара, Л. І. Кучирка // Клініч. та експерим. патологія. - 2014. № 4 (50). - С. 148-151.

19. Хара М. Р. Особливості перекисного окиснення ліпідів та антиоксидантної системи у гонадектомованих самок щурів при моделюванні некротичного пошкодження міокарда та корекції / М. Р. Хара, В. Є. Пелих // Мед. хімія. -2010. - 12, № 1. - С. 80-84. 


\section{REFERENCES}

1. Baraboi, V.A., \& Reznikov, O.H. (2013). Fiziolohiia, biokhimiia i psykholohiia stresu [Physiology, biochemistry and psychology of stress]. Kyiv [in Ukrainian].

2. Boland, T.A., Lee, V.H., \& Bleck, T.P. (2015.) Stress-induced cardiomyopathy. Crit. Care Med., 43 (3), 686-693.

3. Prasad, A., Lerman, A., \& Rihal, C.S. (2008). Apical ballooning syndrome(So-Tsubo or stress cardiomyopathy): a mimic of acute myocardial infarction. Am. Heart J.,155 (3),408-417.

4. Wang, A.R., Dean, S.A., Grebe, S.K., \& Hood, I.C (2016). Fatal catecholamine-induced cardiotoxicity associated with pheochromocytoma: Report of a postpartum case and literature review. Acad. Forensic Pathol., 6 (2), 315-324.

5. Khara, M.R., Shkumbatiuk, O.V., \& Kuchyrka, L.I. (2014). Kharakterystyka stupenia poshkodzhennia miokarda adrenalinom u shchuriv riznoi stati zalezhno vid tryvalosti sposterezhennia ta rivnia statevykh hormoniv [Characteristics of the degree of myocardial damage by adrenaline in different sex rats, depending on the duration of observation and the level of sex hormones]. Visnyk morfolohii - Bulletin of Morphology, 2 (20), 372375 [in Ukrainian].

6. Kazimirko, V.K., Ivanitskaya, L.N., Kutovoy, V.V., Dubkova, A.G., \& Silantyeva, T.S. (2014). Perekisnoe okislenie lipidov: protivorechiya problem [Lipid peroxidation: contradictions of the problem]. Ukr. revmatol. zhurn. - Ukrainian Rheumatology Journal, 3 (57), 13-17 [in Russian].

7. Jiki, Z., Lecour, S., \& Nduhirabandi, F. (2018) Cardiovascular benefits of dietary melatonin: A myth or a reality? Front Physiol., 9, 528.

8. Russel J. Reiter, Dun Xian Tan, Sergio RosalesCorral, Annia Galano, Xin Jia Zhou, \& Bing Xu. (2018). Mitochondria: Central organelles for melatonin's antioxidant and anti-aging actions. Molecules, 23 (2), 509.

9. Glen Pyle, W., \& Tami, A. Martino. (2018). Circadian rhythms influence cardiovascular disease differently in males and females: role of sex and gender. Current Opinion in Physiology, 5, 30-37.

10. Khara, M.R., \& Shkumbatyuk, O.V. (2014). Statevi vidminnosti metabolichnykh zmin $v$ miokardi pry rozvytku nekrotychnoho protsesu na tli melatoninu [Gender differences of metabolic changes in myocardium in the development of necrotic process on the background of melatonin]. Aktualnye problem transportnoy meditsiny Actual Problems of Transport Medicine, 2 (36-II), 47-52 [in Ukrainian].

11. Gavrillov, V.B., \& Mishorudnaya, M.I. (1983). Spektrophotometricheskoye opredelenie soderzhaniya hydroperekisey lipidov v plazme krovi [Spectrophotometric determination of lipid hydroperoxide content in blood plasma]. Lab. delo - Laboratory Case, 3, 33-35 [in Russian].

12. Andreeva, L.I., Kozhemyakin, L.A., \& Kishkun, A.A. (1988). Modifikatsiya metoda opredeleniya perekisey lipidov $v$ teste $s$ tiobarbiturovoy kislotoy [Modification of the method of determination of lipid peroxides in the test with thiobarbituric acid]. Lab. delo - Laboratory Case, 11, 41-43 [in Russian].

13. Chevari, S., Chaba, I., \& Sokey, Y. (1985). Rol superoxiddismutazy $v$ okislitelnykh protsessakh kletki i metod opredeleniya ee $v$ biologicheskom materiale [The role of superoxide dismutase in the oxidative processes of the cell and the method of its determination in biological material]. Lab. delo - Laboratory Case, 11, 678681 [in Russian].

14. Korolyuk, M.A., Ivanova, L.I., \& Mayorov I.G. (1988). Metod opredeleniya aktivnosti katalazy [The method of determining the activity of catalase]. Lab. delo - Laboratory Case, 1, 16-19. [in Russian].

15. Verevkina, N.V., Tochilkin, A.I., \& Popova, N.A. (1977). Kolorimetricheskiy metod opredelenia SH-grupp i SS-sviazei pri pomoschi 5,5-ditiobis (2-nitrobenzonovoi) kisloty [A colorimetric method for the determination of $\mathrm{SH}$ groups and SS bonds in proteins by 5.5-dithiobis (2-nitrobenzoic) acid]. Modern methods in biochemistry. Moscow: Meditsina [in Russian].

16. Kruhlykova, H.O., \& Stutman, Ts.M. (1976). Hlutationperoxydasna ta hlutationreduktazna aktyvnist pechinky shchuriv pislia vvedennia selenitu natriu [Glutathione peroxidase and glutathione reductase activity of rat liver after administration of sodium selenite]. Ukr. biokhim. zhurn. - Ukrainian Biochemical Journal, 48 (2), 227-233 [in Ukrainian].

17. Manchester, L.C., Coto-Montes, A., Boga, J.A., Andersen, L.P., Zhou, Z., Galano, A., Vriend, J., Tan, D.X., \& Reiter, R.J.. (2015). Melatonin: an ancient molecule that makes oxygen metabolically tolerable. J. Pineal Res., 59 (4), 403-419.

18. Khara, M.R., \& Cuchyrka, L.I. (2014). Perekysne okysnennia lipidiv u miokardi pry rozvytku nekrotychnoho protsesu na tli melatoninu ta riznoi aktyvnosti honad [Lipid peroxidation in the myocardium during the development of a necrotic process on the background of melatonin and different activity of the gonads]. Klin. ta eksperem. Patol. - Clinical and Experimental Pathology, 4 (50), 148-151 [in Ukrainian].

19. Khara, M.R., \& Pelykh, V.Ye. (2010). Osoblyvosti perekysnoho okysnennia lipidiv ta antyoxydantnoi systemy u honadektomovanykh samok shchuriv pry modeliuvanni nekrotychnoho poshkodzhennia miokarda ta korektsii [Peculiarities of lipid peroxidation and antioxidant system in gonadectomized female rats in modeling of necrotic myocardial injury and correction]. Med. khimiia - Medical Chemistry, 1, 80-84. [in Ukrainian]. 


\title{
ПОЛОВЫЕ ОТЛИЧИЯ СВОБОДНОРАДИКАЛЬНЫХ ПРОЦЕССОВ В МИОКАРДЕ ПРИ ПОВРЕЖДЕНИИ АДРЕНАЛИНОМ НА ФОНЕ СВЕТОВОЙ ДЕПРИВАЦИИ
}

\begin{abstract}
Резюме
Вступление. Ишемическая болезнь сердца - основная причина смерти, и чаще всего она возникает у мужчин. Среди фракторов риска главным является стресс. При этом нарушается баланс системы прооксиданты/антиоксиданты. Среди антиоксидантов важное место занимает мелатонин, который уменьшает повреждения миокарда в условиях гиперкатехоламинемии. На сегодняшний день недостаточно изучен вопрос относительно гендерного различия кардиопротекторных эфрфектов мелатонина при нарушенной активности пинеальной железы.

Цель исследования - установить половые различия свободнорадикальных процессов в миокарде при развитии некротического процесса на фоне световой депривации.

Методы исследования. В миокарде желудочков самцов и самок крыс определяли активность перекисного окисления липидов (ПОЛ) и антиоксидантной системы при повреждении адреналином. Некроз миокарда моделировали путем введения адреналина (0,5 мг/кг) в мышиу на фроне световой депривации (10 дней полной темноты, освещение 0,5-1 LX). Группа контроля состояла из животных, находящихся в условиях сохраненного режима смены циклов день/ночь (12 ч освещения 500 LX/12 ч темноты 0,5-1 LX).

Результаты и обсуждение. Развитие некротического процесса в миокарде крыс на фроне десятисуточной световой депривации характеризовалось меньшей активацией ПОЛ по сравнению с показателями животных группы контроля. Это подтверждалось меньшим содержанием продуктов ПОЛ в миокарде желудочков. Активность антиоксидантной системы в таких условиях была больше, чем у животных группы контроля, особенно у самок. Эта закономерность свидетельствовала о положительном влиянии предварительной десятисуточной световой депривации на развитие некротического процесса в миокарде, что можно объяснить усиленным синтезом мелатонина, который является антиоксидантом, а также была характерна для крыс обоего пола, но кардиопротекторный эфрфект световой депривации более существенным был у самок.

Вывод. Световая депривация способствует защите сердца от повреждения адреналином, о чем свидетельствуют меньшая активность перекисного окисления липидов и большая активность энзимов антиоксидантной системы, особенно у самок.
\end{abstract}

КЛЮЧЕВЫЕ СЛОВА: световая депривация; некроз миокарда; липопероксидация; половые различия.

\section{GENDER DIFFERENCES OF FREE-RADICAL PROCESSES IN THE MYOCARDIUM AT ADRENALINE DAMAGE ON THE BACKGROUND OF LIGHT DEPRIVATION}

\section{Summary}

Introduction. Coronary heart disease is the leading cause of death and is more common in men. Stress is prevalent risk factors of heart damage. The balance of the oxidant/antioxidant systems is important marker of metabolism disorder im myocardium at stress. It is proved that melatonin as antioxidant reduces adrenalin-induced myocardium necrosis. But, the gender difference of cardioprotective effect of melatonin in conditions of impaired pineal gland has not been sufficiently studied.

The aim of the study - to explore gender differences of lipid peroxidation activity in the myocardium at adrenalininduced damage on the background of light deprivation.

Research Methods. In the myocardium of the ventricles of male and female rats, the activity of lipid peroxidation (LPO) and antioxidant system (AOS) was determined in case of adrenaline damage. Myocardial necrosis was simulated by introducing adrenaline $(0.5 \mathrm{mg} / \mathrm{kg})$ into the muscle against the background of light deprivation (10 days 
of complete darkness, lighting 0.5-1 LX). The control group consisted of animals under conditions of a preserved regime of day/night cycle change (12 hours of lighting 500 LX/12 hours of darkness $0.5-1$ LX).

Results and Discussion. The development of the necrotic process in the rat myocardium on the background of ten-day light deprivation was accompanied by less activation of LPO compared with the indices of the animals of the control group. This was confirmed by a lower content of LPO products in the ventricular myocardium. AOS activity under such conditions was greater than in animals of the control group, especially in females. This regularity testified to the positive effect of preliminary ten-day light deprivation on the development of the necrotic process in the myocardium, which can be explained by enhanced synthesis of melatonin, which is an antioxidant, and was also characteristic of rats of both sexes, but the cardioprotective effect of light deprivation was more significant in females.

Conclusion. Light deprivation helps protect the heart from adrenaline damage, as evidenced by the lower activity of lipid peroxidation and the greater activity of enzymes of the antioxidant system, especially in females.

KEY WORDS: light deprivation; myocardium necrosis; lipoperoxidation; gender difference.

Отримано 29.10.19

Адреса для листування: М. Р. Хара, Тернопільський національний медичний університет імені І. Я. Горбачевського МОз України, майдан Волі, 1, Тернопіль, 46001, Україна, e-mail:khara_m@ukr.net. 